\title{
A Review on Preparation of Betulinic Acid and Its Biological Activities
}

\author{
Hanghang Lou ${ }^{\dagger}, \mathrm{Hao} \mathrm{Li}^{\dagger}{ }^{\dagger}$, Shengliang Zhang, Hongyun Lu and Qihe Chen * $\mathbb{C}$ \\ Department of Food Science and Nutrition, Zhejiang University, Hangzhou 310058, China; \\ louhanghang@zju.edu.cn (H.L.); lhh20210901@126.com (H.L.); 12113064@zju.edu.cn (S.Z.); \\ luhongyun@zju.edu.cn (H.L.) \\ * Correspondence: chenqh@zju.edu.cn; Tel.: +86-0571-8698-4316 \\ + These authors are equally to this manuscript.
}

check for updates

Citation: Lou, H.; Li, H.; Zhang, S.; Lu, H.; Chen, Q. A Review on Preparation of Betulinic Acid and Its Biological Activities. Molecules 2021, 26, 5583. https://doi.org/10.3390/ molecules 26185583

Academic Editors: Xingxian Zhang and Yi Wang

Received: 19 August 2021

Accepted: 2 September 2021

Published: 14 September 2021

Publisher's Note: MDPI stays neutral with regard to jurisdictional claims in published maps and institutional affiliations.

Copyright: (c) 2021 by the authors. Licensee MDPI, Basel, Switzerland. This article is an open access article distributed under the terms and conditions of the Creative Commons Attribution (CC BY) license (https:// creativecommons.org/licenses/by/ $4.0 /)$.

\begin{abstract}
Betulinic acid, a pentacyclic triterpene, is distributed in a variety of plants, such as birch, eucalyptus and plane trees. It shows a wide spectrum of biological and pharmacological properties, such as anti-inflammatory, antibacterial, antiviral, antidiabetic, antimalarial, anti-HIV and antitumor effects. Among them, the antitumor activity of betulinic acid has been extensively studied. However, obtaining betulinic acid from natural resources can no longer meet the needs of medicine and nutrition, so methods such as chemical synthesis and microbial biotransformation have also been used to prepare betulinic acid. At the same time, with the development of synthetic biology and genetic engineering, and the elucidation of the biosynthetic pathways of terpenoid, the biosynthesis of betulinic acid has also been extensively researched. This article reviews the preparation of betulinic acid and its pharmacological activities, in order to provide a reference for the research and utilization of betulinic acid.
\end{abstract}

Keywords: betulinic acid; preparation; biological activities; triterpenes

\section{Introduction}

Triterpenes are a chemically diverse class of compounds, and many among them are of interest from a human health perspective. Betulinic acid (BA, 3-beta-hydroxy-lup20(29)-en28-oic acid, Figure 1B) is a pentacyclic lupane-type triterpenoid that is widely distributed throughout the plant kingdom [1,2]. The chemical structures of lupane-type triterpenoids are shown in Figure 1. Among these compounds, recently, BA has gained considerable interest owing to a variety of biological and pharmacological activities that have been ascribed to this compound, including anti-inflammatory, antibacterial, antiviral, antidiabetic, antimalarial, anti-HIV and antitumor effects [1]. Because of its specific cytotoxicity against tumor cells, BA is considered a future promising antitumor compound [3-5]. Interestingly, despite its great potential for clinical applications, the insufficient supply of BA in its natural hosts is a major challenge in commercializing this compound. Though birch bark is the major plant source for extracting BA, the minute amount of BA in its tissues has limited its production on a large scale for the market [6]. Thus, developing more methods to prepare this compound is a major research area. Chemical synthesis based on betulin (Figure 1A) as the precursor has been reported generally [7-9]. Recently, microbial biotransformation became another approach for converting betulin to BA, but the conversion efficiency is pretty low, and this approach is also limited by the supply of betulin [10]. Though the pharmaceutical and physiological importance of these triterpenoids is known, understanding of their biosynthetic pathways remains limited [11]. Rapid developments in metabolic engineering and synthetic biology provide alternative approaches for the increased production of natural products in microbial hosts [12-15]. The identification of newly identified microbes that convert betulin to BA is recently more intentioned [16], and metabolic engineering of key biosynthetic genes derived from plant sources has been reported as well. As a consequence, 
this review discusses recent developments in biotransformation and metabolic engineering for BA production. The purpose of this review is to describe recently published literature on the derived sources and production of BA and introduce its pharmacological activity. Furthermore, this review presents insights and strategies for the sustainable metabolic engineering of BA in multifarious transgenic organisms.

A

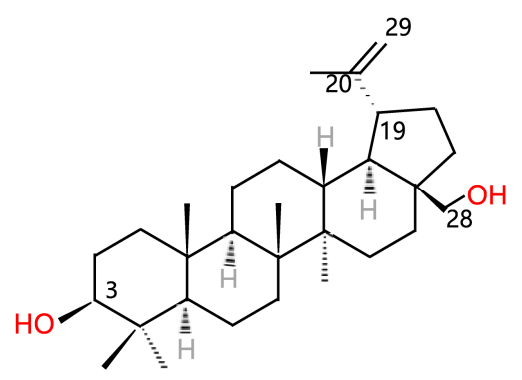

B

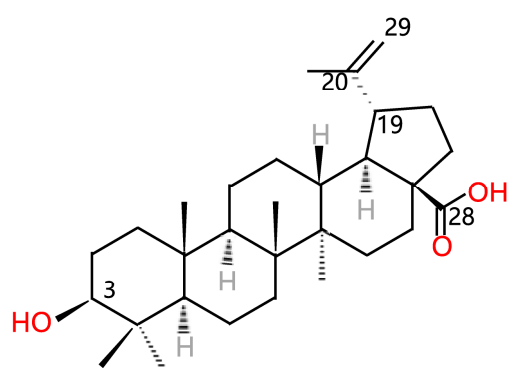

Figure 1. Structures of (A) betulin and (B) betulinic acid.

\section{Preparation of Betulinic Acid}

BA is generally derived from plant sources, such as birch, eucalyptus and plane trees. However, it is well known that the low concentration in plant sources has limited its research and application. To solve these problems, nowadays, more research is focused on the construction of new synthesis methods such as chemical synthesis, biotransformation, metabolic engineering, etc. Herein, we summarize the progress of BA preparation in recent times.

\subsection{Extract Betulinic Acid from Plants}

So far, BA has been mainly found in the outer bark of the white birch tree. The BA concentration in birch bark was found to be about $0.002-2 \%$, and the yield depended on the extraction solvents and methods. Mukherjee et al. [17] used 70\% ethanol to extract BA and obtained a yield of $23.76 \mathrm{mg} / 10 \mathrm{~g}$ birch bark. Kim et al. [18] obtained a comparatively low yield of BA (0.0021\%) from birch bark by ultrasonic extraction. Ethyl acetate was also used in the maceration extraction of BA, and the yield reached $3.07 \mathrm{mg} / \mathrm{g}$ birch bark [19]. To overcome the environmental problems and the production of hazardous waste of the above methods, new environmentally and human-friendly technologies were implemented into BA extraction. As a result, the yield could reach $28.3 \mathrm{mg} / 10 \mathrm{~g}$ birch bark after optimization [20]. Additionally, BA was identified in several other botanical tissues. In 1948, BA was identified in the bark of the plane tree [21]. In 1999, Galgon et al. [22] conducted quantification of BA in the cork of the plane tree. The results showed that the concentration was about 3.3\%. In a comparative study, supercritical fluid extraction using ethanol as the cosolvent of $\mathrm{CO}_{2}$ achieved a high BA extraction yield (4.34\%) from the dried bark of the plane tree (Platanus acerifolia L.) and almost one-third of the organic consumption compared with solid-liquid extraction (SLE), ultrasound-assisted extraction (UAE) and pressurized liquid extraction (PLE) [23]. BA was also found to exist in the leaves, stem and bark of Syzygium aromaticum (L.) Merr. \& L.M. Perry (SA), a tropical evergreen tree [24]. The botanical materials were first extracted in methanol by a Soxhlet extractor, and the extracts were dried into solid. The BA content of the leaf extracts of SA was higher than the content of the stem and bark extracts, which was $16.9 \pm 0.9,3.5 \pm 0.2$ and $3.8 \pm 0.4$ [24]. BA was also detected in Eucalyptus spp., an important fiber source for pulp and paper production. BA could be extracted from the biomass residues of the pulping industry [25-28] and also isolated from Lamiaceae plants [29,30]. Vietnamese researchers isolated BA from the aerial part of Orthosiphon stamineus using ethanol [29]. Machado et al. [30] isolated BA from the dried aerial parts of Rosmarinus officinalis L. Nyasse et al. [31] isolated BA from five Uapaca from Cameroon, and the concentration ranged from 1.5\% to $1.9 \%$. Chinese folk medicine, such as Ziziphus jujube Mill var. spinosa (Bunge) Hu ex. H.F. Chou, was also found as a source of BA [32,33]. Sun et al. [32] and Zhang et al. [33] 
isolated BA from sour jujube fruits and semen Ziziphi spinosae, respectively. Furthermore, Nigerian researchers isolated BA from the roots of Tetracera potatoria [34]. BA was obtained from Souroubea sympetala [35]. Callistemon lanceolatus, an Australian native plant and widely distributed in subtropical regions, was discovered harboring BA too [36]. Lin et al. [37] extracted BA from the aerial roots of Avicennia marina, which was a cosmopolitan species resident in tropical and subtropical regions.

\subsection{Chemical Synthesis}

Because of its various bioactivities, BA is in great need. However, extracting BA from botanical materials is time-consuming, not environmentally friendly and produces a low yield. Thus, extraction is not suitable for large-scale manufacturing. Chemical synthesis is another method to obtain BA. In 1997, Kim et al. [38,39] obtained BA by first oxidizing betulin using Jones reagent-for example, chromium trioxide $\left(\mathrm{CrO}_{3}\right)$, sulfuric acid $\left(\mathrm{H}_{2} \mathrm{SO}_{4}\right)$ and acetone at $0{ }^{\circ} \mathrm{C}$ - and then reducing it using sodium borohydride in THF. The oxidation step oxidized the betulin into betulonic acid by oxidizing the primary carboxylic acid functionality and the secondary hydroxyl functionality to a keto functionality $[38,39]$. The reduction step only reduced the keto functionality of betulonic acid to hydroxyl functionality $[38,39]$ (Figure 2A). To obtain only the b-isomer BA, a five-step synthesis without the reduction step was established [38,39] (Figure 2B). The primary alcohol of BA dissolved in $\mathrm{CH}_{2} \mathrm{Cl}_{2}$ was protected by esterification into a THP ether using dihydropyran (DHP) and pyridinium p-toluene sulfonate (PPTS), and then the secondary alcohol was acetylated using $\mathrm{Ac}_{2} \mathrm{O}$ and pyridine. The THP ether was selectively hydrolyzed and removed using methanol and PPTS, and Jones oxidation could turn the primary alcohol into carboxylic acid. To obtain b-isomer BA, the acetyl group was removed using $\mathrm{K}_{2} \mathrm{CO}_{3}$, methanol and $\mathrm{H}_{2} \mathrm{O}[38,39]$. Gaudet et al. [40] added white birch bark directly with $\mathrm{CrO}_{3}$ absorbed in $\mathrm{Al}_{2} \mathrm{O}_{3}$ in $\mathrm{CH}_{2} \mathrm{Cl}_{2}$ and then used potassium permanganate for further oxidation to harvest BA. Russian scientists also created a method similar to Kim's [9]. Betulin was oxidized to betulonic acid with a pyridine dichromate complex and acetic anhydride in dimethylformamide in a ratio of 2.5:1-3:1, and betulonic acid was reduced to alpha (5\%) and beta (95\%) isomers with sodium boron hydride in C2-4 alcohol [9]. Then, recrystallization of BA from C2-4 alcohol to form a natural isomer of BA from the alpha-isomer took place [9].

The reagents used in the above method were expensive and hazardous; in addition, the process is time-consuming. Thus, Krasutsky et al. [41,42] improved the method of manufacturing BA into one that requires less time and reagents that are less expensive and less toxic (Figure 3). Betulin was first acylated to betulin-3,28-diacetate by heating under reflux for $2-5 \mathrm{~h}$ in acetic anhydride and acetic acid. Then, betulin-3-acetate was obtained via selective deacetylation using aluminum isopropoxide. After, betulin-3-acetate was oxidized to betulin aldehyde-3-acetate with the use of palladium acetate, molecular sieves and oxygen in trifluoromethylbenzene and pyridine at $80-85^{\circ} \mathrm{C}$ for $0.5-4 \mathrm{~h}$. Further, betulin aldehyde-3-acetate was oxidized to betulinic acid-3-acetate with the use of oxygen and cobalt acetylacetonate in trifluoromethylbenzene at $60-65^{\circ} \mathrm{C}$ for $0.5-2 \mathrm{~h}$. Finally, the $\mathrm{C}-3 \mathrm{OH}$ group was deprotected to provide BA [41,42].

However, the substrate was sensitive to degradation. The process needed several steps of protection and deprotection, and although the time needed for the process was reduced compared to Kim's method, it was still time-consuming for commercial use. Menard et al. [8] subjected betulin to a short two-step synthesis to form BA (Figure 4). The C-28 OH group of substrates that dissolved in glacial acetic acid was first electrochemically oxidized to aldehyde using TEMPO. After isolation and purification, a mild oxidizing agent such as $\mathrm{NaClO}_{2}$ in t-butanol oxidized the aldehyde into BA [8]. 


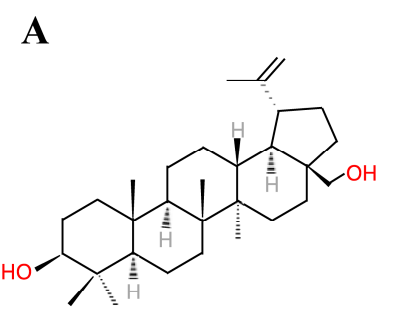

a. betulin

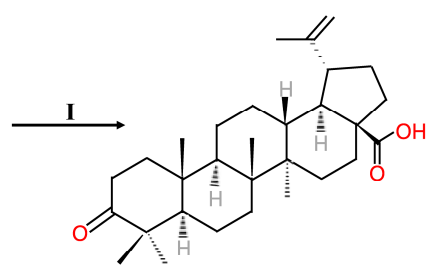

b. betulonic acid

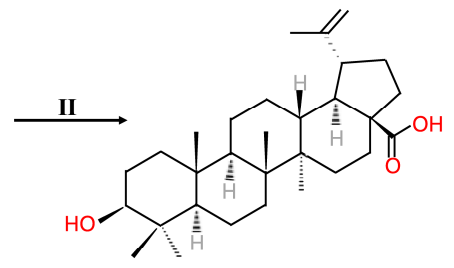

c. betulinic acid

B

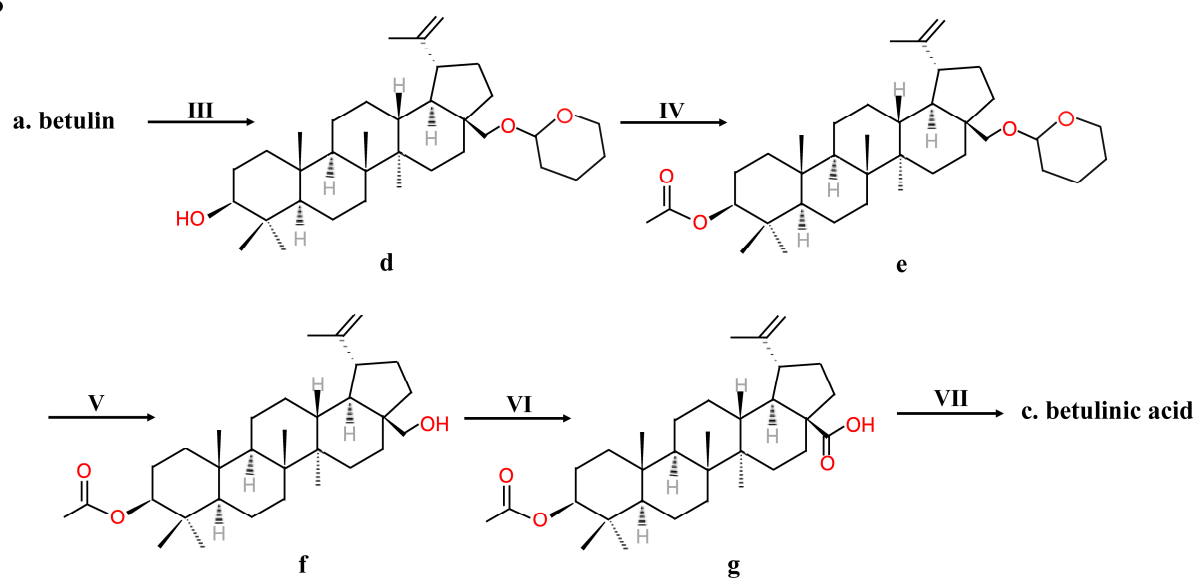

Figure 2. (A) Kim's two-step method for obtaining BA from betulin. (B) Kim's five-step method for obtaining b-isomer BA from betulin. I. Jones oxidation. II. Reduction. III. Primary alcohol THP esterification. IV. Acetylation of the secondary alcohol. V. Removing the THP ester. VI. Jones oxidation. VII. Removing the acetyl group.

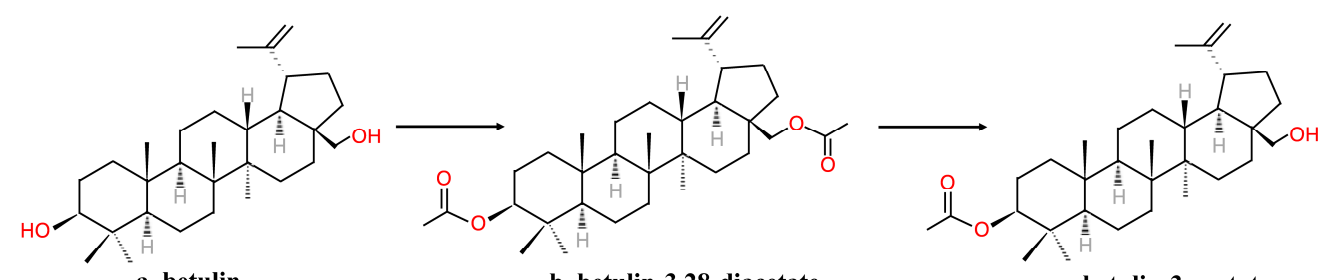

a. betulin

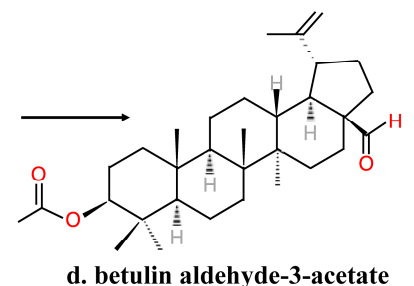

b. betulin-3,28-diacetate

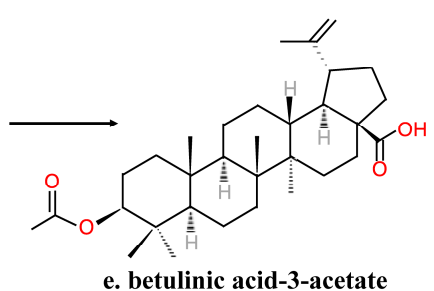

c. betulin-3-acetate

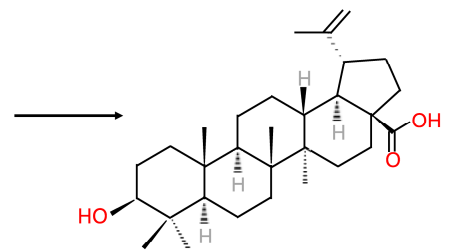

f. betulinic acid

Figure 3. Krasutsky's multistep method of manufacturing betulinic acid.

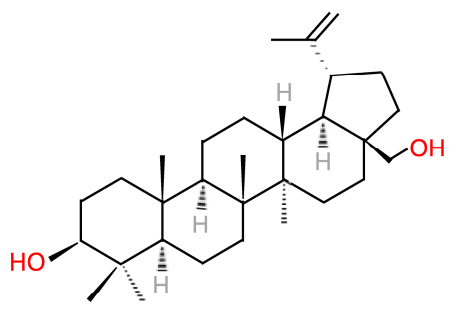

a. betulin

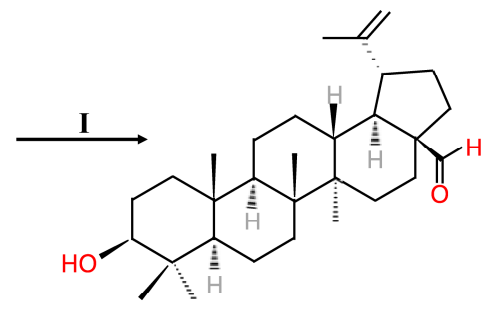

b. betulinaldehyde

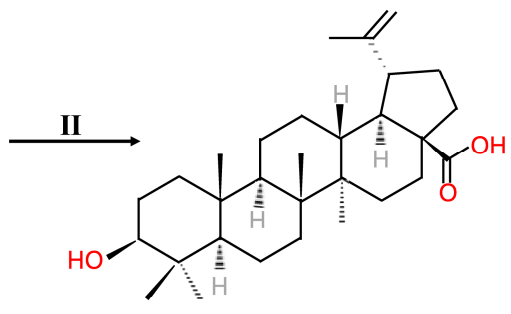

c. betulinic acid

Figure 4. A short two-step procedure synthesizing betulinic acid from betulin. I. TEMPO, H+, electrochemical. II. [O]. 


\subsection{Biotransformation Process}

\subsubsection{Biotransformation by Fungi System}

Obtaining BA from betulin catalyzed by cultured fungi is a possible method. Chen's laboratory has conducted several studies on this [10,43-45]. Chen et al. [43] screened eight fungi for their capability to transform betulin into BA. Under the designed conditions, Armillaria luteo-virens Sacc QH (ALVS), Aspergillus foetidus ZU-G1 (AF) and Aspergillus oryzae (AO) showed a significantly increased effect on BA production [43]. In a further study comparing the effluence of different transformation conditions, ALVS was found to be the most effective strain for BA production, and the optimal condition was G2 (growing cell, preincubation for 3 days, then transformation for 6 days) with a high yield close to $28 \%$ [43]. Liu et al. [10] optimized the biotransformation conditions of A. luteo-virens Sacc ZJUQH1006 , a strain using low-energy $\mathrm{N}^{+}$implantation mutated from A. luteo-virens $\mathrm{Sacc} \mathrm{QH}$, and obtained the predicted optimal of $9.32 \%$, which was $174.53 \%$ of the nonoptimized condition. Fu et al. [44] used an ionic-liquid-containing system as the reaction medium of $A$. luteo-virens Sacc ZJUQH100-6 to produce BA and obtained a yield of $11.4 \%$, which was higher than the PDA aqueous system, the production of which was $8.12 \%$. Cunninghamella blakesleeana was also used in the biotransformation to obtain BA [45]. Feng et al. [45] discovered that C. blakesleeana AS 3.910 was capable of transforming betulin into BA and optimized several parameters of the fermentation process. Qazi et al. [46] also screened five kinds of fungi to select strains that were capable of transforming betulin to BA. Among Microsporum canis, Trichophyton tonsurans, Aspergillus niger, A. niger NIAB-280 and Penicillium spp., M. canis and T. tonsurans showed strong transformation ability [46]. However, the exact BA yield was not revealed in the report. Inonotus obliquus was found to produce BA [47]. Some stimulating methods have been proposed to improve BA production in the liquid fermentation of I. obliquus. Lou et al. [48] investigated the effect of oleic acid, fungal elicitor and the combination of oleic acid and fungal elicitor on the accumulation of BA in submerged culture of I. obliquus. The results showed that oleic acid, fungal elicitor and their combination extremely increased the total BA levels by $78.6 \%, 141.6 \%$ and $404.9 \%$, respectively, as compared to the control [48].

\subsubsection{Tissue Culture}

Tissue culture of plants containing BA in the natural state is also a productive way to obtain BA. However, reports are scarce. The extractions of calli induced from the leaves and flowers of Eucalyptus camaldulensis Dehnh have been found to contain BA, along with several other functional phytochemicals [49].

\subsection{Gene Engineering}

The metabolic engineering biosynthetic pathway in microorganisms to produce terpenoids such as BA is an attractive method, and it has advantages over chemical synthesis or extraction from botanical materials. Triterpenoid is synthesized in the mevalonate pathway, in which the mevalonate transforms into farnesyl pyrophosphate (FPP) in several steps. Under the catalysis of squalene synthase, two molecules of FPP condense with reduction by NADPH to form squalene. Then, the squalene is oxidized into 2,3-oxidosqualene. The cyclization of 2,3-oxidosqualene is the first step for triterpenoid saponins synthesis [50-54]. Fukushima et al. [55] confirmed the BA and other triterpenoid production activity of CYP716A12 (Cyt P450 monooxygenase 716A12) from Medicago truncatula by expressing it in transgenic yeast. The synthesis of lupeol from 2,3-oxidosqualene was catalyzed by lupeol synthase (LUS), followed by the catalysis of CYP716A12, which was capable of carboxylation at the C-28 position to transform lupeol into betulin and BA further [55]. After that, a new CYP716A was identified and discovered to have BA synthesis capabilities [56]. Huang et al. [56] identified CYP716AL1 as the triterpene C-28 oxidase in Catharanthus roseus. The coexpression of CYP716AL1 from C. roseus and AtLUP1 from Arabidopsis thaliana in Saccharomyces cerevisiae system resulted in BA production [56]. However, linear introduction of the enzymes in the BA metabolic pathway perturbed the redox balance in 
cells and eventually resulted in the inhibition of cell growth [57]. Li et al. [57] constructed nine strains of yeast harboring key genes of fatty acid synthesis and BA production and modulated the carbon flux by using different promoters for those key genes. Through this measure, it was established that a higher BA production yeast with balanced carbon flux between BA synthesis and fatty acid synthesis could be constructed [57]. Considering that the cofactors NADPH and oxygen are vital for BA synthesis, Li et al. [58] managed the intracellular supply of NADPH and oxygen by expressing mutant 2,3-butanediol dehydrogenase (mBDH1) and yeast codon-optimized Vitreoscilla hemoglobin (mvhb) to modulate BA production in S. cerevisiae. The results showed that using acetoin with the expression of $\mathrm{mBDH} 1$ can increase BA production with normal cell growth, and the expression of mvhb inhibits cell growth but increases BA production [58].

\section{Biological Activities}

BA has gained a lot of concentration and considerable interest in research because of its potent physiological and pharmacological activities. It has been reported that BA has a variety of biological and pharmacological effects, including antitumor, anti-inflammatory, anti-HIV, antidiabetic and other activities such as antibacterial, antiviral, antimalarial and so on [1]. Thus, BA was considered to be a promising potential drug compound. Some of the most interesting and important biological activities are discussed below.

\subsection{Antitumor Activity}

The usual treatments for cancer are chemotherapy and surgery. However, these treatment means are always accompanied by several potential side effects. Recently, it was discovered that immunomodulatory plant products have anticancer effects, some even with no side effects. BA is considered a future promising antitumor compound and it is effective for many types of cancer (Table 1). In 1995, Pisha et al. [59] first discovered that BA is a selective inhibitor of human melanoma. Since then, the antitumor activity of BA has been extensively reported. According to reports, BA has a curative effect on leukemia, malignant head and neck cancer, colorectal carcinoma, breast tumor, lung carcinoma, hepatoma, cervical cancer, ovarian cancer and other carcinomas $[5,60,61]$. One study examined the cytotoxicity of BA against human promyelocytic leukemia HL-60 cells. The mean concentration of CK for inhibiting cell proliferation by $50 \%\left(\mathrm{IC}_{50}\right)$ was $5.7 \mu \mathrm{m}$ after $72 \mathrm{~h}$ [62]. In addition to causing apoptosis, BA also induced HL-60 differentiation by $10 \%$ to $20 \%$, and cotreatment of BA and $1 \alpha, 25$-dihydroxyvitamin D3 enhanced this differentiation [62]. The result was confirmed by a study showing the $\mathrm{IC}_{50}$ of $\mathrm{BA}$ was $2.60 \mu \mathrm{g} / \mathrm{mL}$ for HL-60 and $2.10 \mu \mathrm{g} / \mathrm{mL}$ for the WEHI-3B cell line [63]. Khan et al. [64] also found the $\mathrm{IC}_{50}(48 \mathrm{~h})$ of BA toward HL- 60 was $8 \mu \mathrm{m}$. Another study compared BA with ten kinds of standard therapeutics, and the results showed that BA was more potent than nine of the ten therapeutics [65]. The intracellular signaling pathway of BA-induced apoptosis of leukemia cells was that BA stimulated mitochondria to release cytochrome $c$ and Smac and cause further apoptosis reactions [65]. Wu et al. [66] found that BA was cytotoxic to leukemia K-562 cells with an $\mathrm{IC}_{50}$ of $21.26 \mu \mathrm{g} / \mathrm{mL}$ at $24 \mathrm{~h}$, and BA inhibited K-652 proliferation by induced apoptosis in a time- and dose-dependent manner and cell cycle arrest. Kesseler et al. [67] treated several cell lines of five kinds of cancer with BA to confirm that BA exerts cytotoxicity on cancers of different tissues. Mullayer et al. [61] developed a liposome formulation of BA to attenuate its weak hydrosolubility and delivered a BAcontaining liposome into mice xenografted with human colon and lung cancer tumors. This treatment significantly reduced the tumor growth and increased the survival rate of mice with the tumor [61]. The tumor volume of colon cancer SW480 in treated mice was about $1 / 3$ of the control [61]. The BA-containing liposome treatment reduced more than half of the tumor volume of mice with lung cancer A549 compared with the control treatment [61]. In an article studying the mechanism of BA's antitumor effects on colon tumors, researchers treated RKO and SW480 colon cancer cell lines with BA and found that BA significantly inhibited cell growth after $5 \mathrm{~h}$ and induced apoptosis [68]. Researchers 
also concentrated on the effect of BA on the chemoresistant cell lines of colon cancer. Cell lines resistant to 5-fluorouracil (5-FU) (SUN-C5/5FU-R), IRT (SUN-C5/IRT-R) and OXT (SUN-C5/OXT-R) were isolated from the wild-type colon cancer cell line (SUN-C5/WT), and BA alone was effective against wild type, 5FU-R and OXT-R. BA combined with OXT was capable of inducing the apoptosis of the SNU-C5/OXT-R cell [69]. Aisha et al. [70] not only found that BA inhibited the growth of colon cancer cell HCT116 in a dose-dependent manner but also that the combination of $2.5 \mu \mathrm{g} / \mathrm{mL} \alpha$-mangostin and BA could significantly increase the cytotoxicity of BA. BA combined with cisplatin showed reduced cytotoxicity in subcytotoxic BA concentrations, but when the BA concentration was above $7.5 \mu \mathrm{g} / \mathrm{mL}$, combined with cisplatin, $100 \%$ of colorectal cancer cells were killed.

Researchers also studied BA's effect on the cell lines of prostate cancer. Rabi et al. [71] treated androgen-refractory human prostate cancer cells PC-3 with BA, and the cell line they used expressed high constitutive NF- $\mathrm{B}$, which partly led to the chemoresistance of androgen-refractory prostate cancer. The results revealed that the treatment of BA inhibited DNA binding and reduced the nuclear levels of NF-kB/p65 [71]. BA treatment reduced IKK activity and stimulated $I \kappa B \alpha$ phosphorylation at serine $32 / 36$ and subsequent degradation. BA's inhibitory effect on the activation of NF- $\kappa B$ induced by TNF $\alpha$ through the I $\kappa \mathrm{B} \alpha$ pathway reduced TNF $\alpha$-induced apoptosis [71]. In a study intended to depict the role of antiapoptotic protein Mcl-1 in resisting DNA damage induced by chemotherapy in prostate cancer, BA combined with ENMD-1198, an antitumor agent, significantly increased apoptotic/necrotic cell death and inhibited metastasis by decreasing Mcl-1, which led to increased DNA damage [72]. BA isolated from the flower stalks of Prunella vulgaris var. lilacina was reported to have a significant inhibitory effect on estrogen-mediated signaling [18]. When MCF7 breast cancer cells were treated with BA, the synthesis of estrogen-responsive gene growth regulation by estrogen in breast cancer 1 (GREB1) mRNA was significantly inhibited, ERE-dependent luciferase activity was significantly suppressed, and estrogen receptor $\alpha(\operatorname{Er} \alpha)$-mediated signaling was suppressed by inhibiting Era mRNA synthesis to suppress the ER $\alpha$ protein levels.

Multiple myeloma (MM) is a type of severe cancer that has a higher disease incidence among people over 40 , especially in elderly people over 60 . BA is capable of inducing apoptosis in MM cells. A study treating multiple myeloma cell lines U266 and MM.1S (dexamethasone sensitive) with BA found that BA inhibited the signal transducer and activator of transcription protein 3 (STAT3) activation [73]. The induced expression of protein tyrosine phosphatase SHP-1 and the silencing of the SHP-1 gene further maintained BA-induced cell apoptosis [73]. The combination therapy of BA with thalidomide and bortezomib enhanced the apoptosis-inducing effect of chemotherapeutics [73]. One of the mechanisms through which BA selectively kills cancer cells is the alternation of mitochondrial permeability. Potze et al. [74] suggested that BA mediates mitochondrialdependent cell apoptosis by inhibiting the activity of stearoyl-CoA-desaturase (SCD-1), which catalyzes the conversion of newly synthesized saturated fatty acids to unsaturated fatty acids, thereby influencing the saturation levels of cardiolipin (CL), which results in ultrastructural changes in mitochondrial and cytochrome c release in tumor cells. This mechanism was found in all four cells, including HeLA cells, A549 cells, MCF-7 cells and RKO cells [74].

Table 1. Effect of BA on different cancer cell lines.

\begin{tabular}{|c|c|c|c|}
\hline Cancer Type & Cell Line/Animal & Dose & Reference \\
\hline \multirow{6}{*}{ Leukemia } & Cell line: HL-60 & $\mathrm{IC}_{50}=5.7 \mu \mathrm{m}(72 \mathrm{~h})$ & {$[62]$} \\
\hline & Cell line: K-562 & $\mathrm{IC}_{50}=21.26 \mu \mathrm{g} / \mathrm{mL}(24 \mathrm{~h})$ & {$[66]$} \\
\hline & Cell line: K-562 & $\mathrm{IC}_{50}=12.5 \mu \mathrm{g} / \mathrm{mL}(48 \mathrm{~h})$ & [75] \\
\hline & Cell line: HL-60 & $\mathrm{IC}_{50}=2.60 \mu \mathrm{g} / \mathrm{mL}(72 \mathrm{~h})$ & \\
\hline & Cell line: WEHI-3B & $\mathrm{IC}_{50}=2.10 \mu \mathrm{g} / \mathrm{mL}(72 \mathrm{~h})$ & [63] \\
\hline & Cell line: HL-60 & $\mathrm{IC}_{50}=8 \mu \mathrm{m}(48 \mathrm{~h})$ & [64] \\
\hline
\end{tabular}


Table 1. Cont.

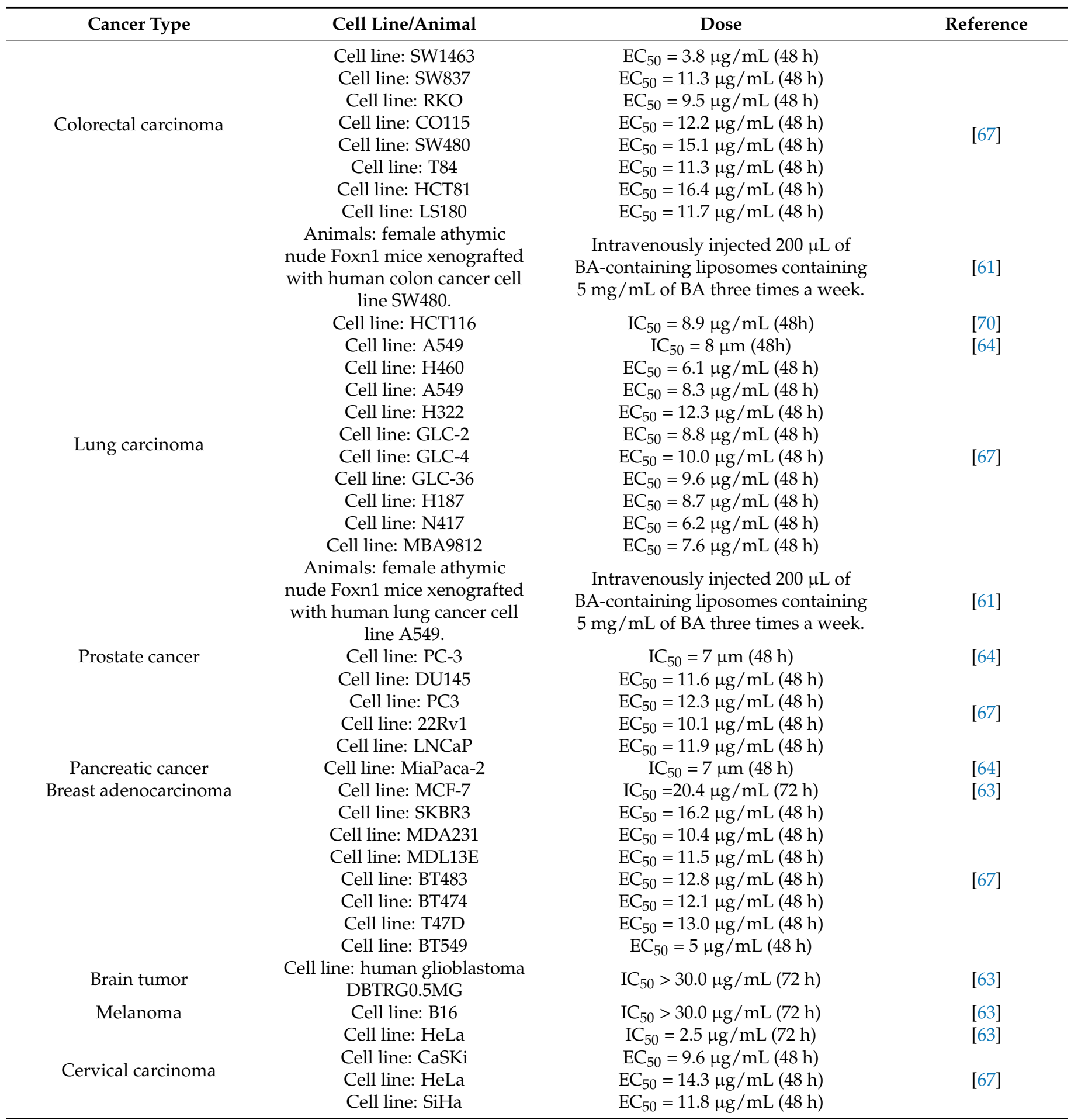

\subsection{Anti-Inflammatory Activity}

Inflammation has been regarded as the main factor of many diseases, as it can lead to cell death, organ-specific damage or some cancers. In recent years, many studies have confirmed that BA has an anti-inflammatory effect. Costa et al. [76] reported that in a mouse model of endotoxic shock, BA exhibited potent anti-inflammatory activity. Administration of BA protected all mice from a lethal dose of lipopolysaccharide (LPS), significantly inhibited tumor necrosis factor (TNF)- $\alpha$ release induced by LPS and increased the interleukin (IL)-10 level in serum. In vitro experiments also showed that BA treatment inhibited TNF- $\alpha$ 
and NO in LPS-activated macrophages and enhanced the production of IL-10 [76]. To evaluate the effect of BA on septic acute lung injury (ALI), Lingaraju et al. [77] set up a cecal ligation and puncture (CLP) model in mice pretreated with BA. Administration of 10 and $30 \mathrm{mg} / \mathrm{kg}$ of BA significantly improved survival against sepsis and attenuated lung injury. In addition, BA inhibited nuclear factor-kappa B (NF-kB) expression in the lung and decreased levels of cytokine, intercellular adhesion molecule-1 (ICAM-1), monocyte chemoattractant protein-1 (MCP-1) and matrix metalloproteinase-9 (MMP-9) [77]. Nader et al. [78] also assessed the effect of BA on LPS-induced ALI by evaluating neutrophil recruitment and inflammation mediators. Pretreatment of $25 \mathrm{mg} / \mathrm{kg}$ BA by oral seven days before LPS nasal instillation significantly inhibited increased lipid peroxidation, expression of tumor necrosis- $\alpha$ (TNF- $\alpha$ ), transforming growth factor-b1 (TGF-b1) and inducible nitric oxide synthase (iNOS) [78]. BA pretreatment also attenuated pulmonary edema and Evans blue extravasation in lung tissue [78]. BA from Erythrophleum ivorense (A Chev.) was applied in chicken injected with carrageenan in the right footpad to evaluate its anti-inflammatory properties [79]. BA exhibited a significant anti-inflammatory effect by reducing carrageenan-induced edema [79]. Viji et al. [80] treated LPS-stimulated human peripheral blood mononuclear cells (hPBMCs) with BA to identify the mechanism through which BA exhibits anti-inflammatory effects and employed mice of LPS-induced endotoxin shock as an in vivo model. In hPBMCs, BA suppressed cyclooxygenase-2 (COX-2) expression and prostaglandin $\mathrm{E}_{2}\left(\mathrm{PEG}_{2}\right)$ production by inhibiting extracellular regulated kinase (ERK) and Akt phosphorylation and thereby modulated the NF-KB signaling pathway [80]. Interestingly, BA significantly decreased the mortality of mice against endotoxin shock and inhibited the production of $\mathrm{PEG}_{2}$ in two of the most susceptible organs, lungs and livers [80]. Moreover, BA reduced reactive oxygen species (ROS) formation and the release of lactate dehydrogenase [80]. Another experiment that evaluated the in vitro inhibitory effect of BA on bovine prostaglandin synthase showed that $200 \mu \mathrm{g} / \mathrm{mL} \mathrm{BA}$ inhibited the enzyme by $52 \%$ [81]. Recio et al. [82] assessed the anti-inflammatory effect using a model of 12-O-tetradecanoylphorbol-13-acetate (TPA)-induced ear edema, and BA at a dose of $0.5 \mathrm{mg}$ /ear significantly reduced edema by $86.2 \%$. BA administered orally at a dose of $10 \mathrm{mg} / \mathrm{kg}$ reduced inflammation by $45.6 \%$ [82]. In a similar study, $0.5 \mathrm{mg} / \mathrm{ear}$ of BA resulted in a decrease in neutrophil infiltration by $29 \%$ [83]. In a mice model with paw edema induced by carrageenin and serotonin, oral administration of BA at 50 and $100 \mathrm{mg} / \mathrm{kg}$ significantly reduced paw edema [84]. Krogh et al. [85] extracted BA from Ipomoea pescaprae (L.) R. Br. and assessed its antinociceptive and anti-inflammatory properties. It was found that pretreatment of BA at a dose of $10 \mathrm{mg} / \mathrm{kg}$ attenuated inflammatory pain by $50 \%$ in mice whose paws were injected with formalin [85]. BA from Prunello vulgaris modestly inhibited the nitric oxide production in cultured murine macrophage RAW 264.7 cells [86]. Huguet et al. [87] tested 11 natural compounds on their anti-inflammatory effects; among them, BA inhibited mouse ear edema induced by mezerein-, 12-deoxyphorbol-13-tetradecanoate (DPT) and 12-deoxyphorbol-13-phenylacetate (DPP) by $48 \%, 51 \%$ and $61 \%$, respectively. Additionally, $1 \mathrm{~h}$ pretreatment of BA of bradykinin-induced mouse paw edema caused significant inhibition by $54 \%$ [87].

\subsection{Anti-HIV Activity}

BA isolated from the leaves of Syzigium claviflorum was reported to have an inhibitory effect against HIV replication in H9 lymphocyte cells [88]. This study presented that BA inhibited HIV replication in $\mathrm{H} 9$ cells with an $\mathrm{EC}_{50}$ of $1.4 \mu \mathrm{m}$ but exhibited inhibition against C9 cell growth with an $\mathrm{IC}_{50}$ of $13 \mu \mathrm{m}$ [88]. Reverse transcriptase (RT) was vital for the replication of HIV; thus, inhibition against RT is thought to be a promising prophylactic method against acquired immunodeficiency syndrome (AIDS). Akihisa et al. [89] screened 55 triterpenoids and found that 20 triterpenoids showed inhibitory activities on purified HIV-1 with $\mathrm{IC}_{50}$ values less than $5.0 \mu \mathrm{m}$, including BA. In addition, BA was shown to be a potent HIV-1 RT inhibitor [89]. Many studies have focused on the anti-HIV effect of BA 
derivatives. These activities include blocking the entry of HIV into cells [90] and inhibiting HIV protease [91], which will be elaborated on later.

\subsection{Antidiabetic Activity}

Diabetes is a common disease in today's society and leads to a great number of deaths and disabilities. Patients mainly suffer from type 2 diabetes mellitus (T2DM). BA is considered a novel antidiabetic agent. Kim et al. [92] demonstrated that BA attenuates hyperglycemia by inhibiting hepatic glucose production through modulation of the CAMKK-AMPK-CREB pathway. In vitro, BA significantly reduced hepatic glucose production, activated $\mathrm{p}$-adenosine $5^{\prime}$-monophosphate-activated protein kinase (AMPK) and inhibited the expression of phosphorylated cAMP response element-binding protein (CREB). In vivo, BA decreased the plasma glucose, triglyceride, and insulin resistance index in high-fat diet-fed ICR mice [92]. In addition, BA has protective effects on some diabetes complications. Yoon et al. [93] treated diabetic apolipoprotein-E gene knockout mice with BA, and the results indicated that BA has positive effects on early atherosclerosis. BA treatment for 12 weeks resulted in lower systolic blood pressure, blood urea nitrogen, triglyceride and total cholesterol levels [93]. BA-treated mice also had better blood glucose, insulin, glucose-tolerant results and homeostasis model assessment of insulin resistance index. Atherosclerotic lesions such as roughened endothelial layers were attenuated [93]. At the molecular level, BA downregulated the reduction of endothelial nitric oxide synthase (eNOS) expression, which resulted in the following inhibition of intracellular adhesion molecule 1 (ICAM-1) and endothelin 1 (ET-1) expression [93]. Diabetic nephropathy induced by intraperitoneally injected streptozotocin was also studied. Xie et al. [94] demonstrated the protective effect of BA on rats with diabetic nephropathy. Intragastric administration of BA significantly decreased the inflammatory cytokines such as IL-6, IL-1 $\beta$ and TNF- $\alpha$ in blood and kidney tissue. The histopathological condition of the kidney was ameliorated, and the activities of SOD and CAT were boosted [94]. The phosphorylation of AMPK, NF- $\kappa$ B and I $\mathrm{B} \alpha$ and the expression of NF-E2-related factor 2 (Nrf2) and heme oxygenase (HO)-1 in renal tissue were also reduced by BA treatment [94]. Another similar study using male mice with streptozotocin-nicotinamide (STZ-NA)-induced diabetic nephropathy also revealed the preventive effects of BA [95]. Compared to diabetic mice, BA-treated diabetic mice have increased blood albumin levels and decreased blood urea nitrogen, plasma creatine and renal histopathology levels [95]. However, Ahangarpour et al. [96] studied the effects of BA on the male reproductive system of STZ-NA-induced diabetic mice and found that BA had negative effects on the male reproductive system. BA treatment on diabetic mice even resulted in greater plasma testosterone level reduction, a higher seminiferous tubule vacuole number and a smaller diameter of seminiferous tubules than the diabetes group [96]. Wang et al. [97] also reported that BA ameliorates diabetic renal inflammation and fibrosis. BA suppressed fibronectin expression in high-glucoseinduced mesangial cells and kidneys of diabetic rats by inhibiting NF- $\mathrm{kB}$ activity and the degradation of $I_{\kappa} \mathrm{B} \alpha$. BA also decreased the DNA binding activity and transcriptional activity of NF- $\mathrm{KB}$ in high-glucose-induced glomerular mesangial cells and increased the interaction between $\mathrm{I} \kappa \mathrm{B} \alpha$ and $\beta$-arrestin2 in mesangial cells [97].

\subsection{Antimalarial Activities}

Malaria is one of the most important tropical diseases that has a high morbidity and mortality rate and mainly affects the population and economic development of developing countries. In early 1999, BA was evaluated on its antiplasmodial effects [98]. Steele et al. [98] isolated BA from the root bark of Uapaca nitida Mu"ll-Arg. (Euphorbiaceæ) and tested its in vitro and in vivo antimalarial effects. The $\mathrm{IC}_{50}$ values of $\mathrm{BA}$ against chloroquine-resistant (Kl) and chloroquine-sensitive (T9-96) Plasmodium falciparum were 19.6 and $25.9 \mu \mathrm{g} / \mathrm{mL}$. De Sa et al. [99] studied the antimalarial activity of BA and its derivatives and found that they showed antiplasmodial activity against chloroquine-resistant Plasmodium falciparum parasites in vitro. The $\mathrm{IC}_{50}$ value of $\mathrm{BA}$ was 9.89 , and treatment of mice infected with 
Plasmodium berghei with BA showed a dose-dependent decrease in parasitemia. This indicates that BA is a candidate for the development of new antimalarial drugs. Olanlokun et al. [100] purified BA from Alstonia boonei and found that BA demonstrated antiplasmodial activities using chloroquine susceptible (NK 65) and resistant (ANKA) strains of Plasmodium berghei. In a previous study, Plasmodium infection led to liver mitochondrial pathology, accompanied by nonselective apoptotic effects of antimalarial drugs in liver mitochondria [101]. BA opened mitochondrial permeability transition pore (mPT), increased mitochondrial $\mathrm{F}_{1} \mathrm{~F}_{0}$ ATPase activity and decreased lipid peroxidation and DNA fragmentation. Additionally, the authors found that BA mechanistically prevented and disrupted the secondary structure of mATPase (mouse) with RMSD $>2\left(\mathrm{RMSD}=2.34^{\circ} \mathrm{A}\right)$ by molecular dynamics simulation studies against falcipain-2, dihydrofolate reductase, dihydropteroate synthase and mitochondrial $\mathrm{F}_{1} \mathrm{~F}_{0}$ ATPase (F-2- BA, DHFR- BA, DHPSBA and mATPase- BA, respectively) [100]. Furthermore, some BA derivatives have been studied for antimalaria effects $[102,103]$. A series of BA / betulin-based dimer and hybrid compounds were analyzed in vitro against malaria parasites and human cytomegalovirus (HCMV), and Karagoz et al. found that the BA / betulin and artesunic acid hybrids 11 and 12 showed the most potent activities against P. falciparum and HCMV [102].

\subsection{Other Activities}

BA has been reported to have several other bioactivities beneficial to multiple organs. Several papers have indicated that BA attenuates ethanol-induced liver damage. Szuster-Ciesielska et al. [104] tested the effect of betulin and BA on ethanol-induced hepatic stellate cell activation. Preincubation with $1 \mu \mathrm{M}$ BA significantly suppressed ethanolinduced ROS production and migration in hepatic stellate cells (HSCs) and also inhibited TNF- $\alpha$ production [104]. Significant inhibition of TGF-b production was observed after $24 \mathrm{~h}$ of preincubation with 1 or $5 \mu \mathrm{M}$ BA [104]. BA decreased the ethanol-induced metalloproteinase-2 (MMP-2) expression in a concentration-dependent manner and downregulated tissue inhibitors of metalloproteinases (TIMP-1 and TIMP-2) modestly [104]. BA suppressed c-Jun N-terminal kinase (JNK) signal transduction and inhibited the nuclear factor- $\kappa B(N F \kappa B)$ pathway by inhibiting the phosphorylation of NFkB and IкB [104]. The phosphorylation of Smad 3 was inhibited by BA and thereby suppressed tumor growth factor- $\beta 1$ (TGF- $\beta 1$ ) signaling [104]. Jain et al. [105] assessed the hepatoprotective effect of BA from Tecomella undulata. Pretreatment of BA prevented the depletion of hepatic antioxidants superoxide dismutase (SOD) and catalase (CAT), reduced glutathione (GSH) and ascorbic acid (AA) and decreased the $\mathrm{CCl}_{4}$-induced $\mathrm{LPO}$ level [105]. BA also attenuated the elevation of aspartate aminotransferase (AST) and alanine aminotransferase (ALT) plasma level, as well as $\mathrm{CCl}_{4}$-induced cellular changes, including extensive vacuolation, centrilobular necrosis and nuclear condensation [105]. In another mice model, of which liver damage was induced by alcohol, pretreatment of BA also exerted hepatoprotective effects by improving the redox system in the liver [106]. Wan et al. [107] induced liver fibrosis in Wistar rats by intraperitoneal injection of $200 \mathrm{mg} / \mathrm{kg}$ thioacetamide (TAA) and used it as a model to evaluate the effects of BA. Intragastric administration of 20 or $50 \mathrm{mg} / \mathrm{kg}$ BA every day increased serum ALT and AST and significantly attenuated hepatic hydroxyproline [107]. Moreover, BA reduced the expression of $\alpha$-smooth muscle actin ( $\alpha$-SMA) and collagen-I [107]. BA's hepatoprotective effects are not only underlain by preventing the liver damage induced by chemicals but also by antiviral activities. BA extracted from Avicennia marina was tested for its hepatitis $C$ virus (HCV) suppression effects [37]. BA inhibited HCV replication in Ava 5 replicon cells and in a cell-culture-derived infectious HCV particle system by reducing the phosphorylation of NF-KB and ERK $1 / 2$ of the MAPK pathway, which led to the suppression of COX-2 expression [37].

$\mathrm{BA}$ also exhibits renal-protective effects. Renal fibrosis is an end-stage renal disease symptom that develops from chronic kidney disease (CKD). In this situation, abnormal accumulation of the extracellular matrix leads to loss of kidney tissue and function [108]. In induced chronic kidney disease rats, BA treatment significantly reversed the histological 
changes and abnormal regulation of the metabolic pathway induced by CKD [109]. The upregulated profibrotic protein levels in kidney tissue of CKD rats such as transforming growth factor $\beta$ (TGF- $\beta$ ), connective tissue growth factor (CTGF), hydroxyproline, collagen type I and fibronectin were inhibited by BA treatment [109]. Dilatation of tubules and glomerular degeneration and vacuolation with deposition of collagen fibers were attenuated by BA [109]. Xia et al. [110] reported that BA had cardioprotective effects against myocardial ischemia-reperfusion injury (MIRI). In an open-chest anesthetized rat model with MIRI induced by left anterior descending occlusion followed by reperfusion, BA treatment reduced serum creatinine kinase $(\mathrm{CK})$ and lactate dehydrogenase (LDH) levels, attenuated the apoptosis of cardiomyocytes demonstrated by TUNEL assay results and decreased the $\mathrm{Bax} / \mathrm{Bcl}-2$ ratio [110]. Ischemia-reperfusion injury also occurs in cerebral tissues and causes neuronal injury. BA protected against this ischemia-reperfusion injury in a mice model by enhancing blood flow and reducing oxidative stress and nitrosative stress [111]. Moreover, BA has shown therapeutic potential in treating hypothyroidism, an endocrine disorder prevalent in male and female adults. Oral administration of BA in propylthiouracil (PTU)-induced hypothyroidism in female rats decreased the thyroidstimulating hormone level increased by PTU and attenuated histopathological changes in thyroid follicles [112].

Furthermore, BA extracted from Rosmarinus officinalis L. has shown antidepressant-like effects [30]. BA administered by the oral route significantly decreased the immobility time in the tail suspension test and did not present any significant differences in the locomotion of the open-field test, suggesting that BA may have a promising anti-immobility effect [30]. Jine et al. [113] suggested that BA is a potential biological response modifier and may have an immune-enhancing effect. Oral administration of BA increased the total number of lymphocytes in immune organs and modified the ratio of T-cell subsets in mice. In sheep, red blood cell immunized mice, orally administered $5 \mathrm{mg} / \mathrm{kg}$ BA five times in $24 \mathrm{~h}$, increased the number of plaque-forming cells but inhibited the production of anti-SRBC antibodies on the fourth day after immunization [113]. Kim et al. [114] reported that BA exerted antiobesity effects by influencing the absorption of lipids from the small intestine by inhibiting pancreatic lipase and accelerating lipolysis in adipose tissues. In addition to these bioactivities, BA has been reported to be useful in aquaculture. The bioactive component of Souroubea sympetala, betulinic acid, significantly reduced the cortisol response to net confinement of rainbow trout Oncorhynchus mykiss and attenuated the cortisol response to adrenocorticotropic hormone of the head kidney tissue in vitro [115].

\section{Conclusions}

BA has a variety of biological activities and low toxicity, and it is a very valuable natural product. Recent studies have shown that BA has many biological activities, such as antitumor, anti-HIV, anti-inflammatory, antibacterial, antimalaria effects and so on. Particularly, betulinic acid exhibits potent activities in antitumor aspects; hence, it has attracted widespread attention and seems a promising experimental antitumor drug. In recent times, the research on the preparation of BA has gradually increased with the continuous development of synthetic biology and basic genetic engineering. More and more methods have also been discovered to prepare BA to solve supply problems.

Author Contributions: Investigation, H.L. (Hanghang Lou) and H.L. (Hao Li); resources, H.L. (Hongyun Lu); data curation, H.L. (Hanghang Lou) and S.Z. (Shengliang Zhang); writing-original draft preparation, H.L. (Hanghang Lou) and H.L. (Hao Li); writing-review and editing, Q.C. All authors have read and agreed to the published version of the manuscript.

Funding: This study was financially supported by Public Projects of Zhejiang Province (LGF18C200003), China.

Institutional Review Board Statement: Not applicable.

Informed Consent Statement: Not applicable. 
Data Availability Statement: Data sharing not applicable. No new data were created or analyzed in this study. Data sharing is not applicable to this article.

Conflicts of Interest: The authors declare no conflict of interest.

Sample Availability: Samples of the compounds are not available from the authors.

\section{References}

1. Yogeeswari, P.; Sriram, D. Betulinic acid and its derivatives: A review on their biological properties. Curr. Med. Chem. 2005, 12, 657-666. [CrossRef]

2. Hordyjewska, A.; Ostapiuk, A.; Horecka, A.; Kurzepa, J. Betulin and betulinic acid: Triterpenoids derivatives with a powerful biological potential. Phytochem. Rev. 2019, 18, 929-951. [CrossRef]

3. Zuco, V.; Supino, R.; Righetti, S.C.; Cleris, L.; Formelli, F.J.C.L. Selective cytotoxicity of betulinic acid on tumor cell lines, but not on normal cells. Cancer Lett. 2002, 175, 17-25. [CrossRef]

4. Fulda, S. Betulinic Acid for cancer treatment and prevention. Int. J. Mol. Sci. 2008, 9, 1096-1107. [CrossRef]

5. Fulda, S. Betulinic acid: A natural product with anticancer activity. Mol. Nutr. Food Res. 2009, 53, 140-146. [CrossRef]

6. Jager, S.; Trojan, H.; Kopp, T.; Laszczyk, M.N.; Scheffler, A. Pentacyclic Triterpene Distribution in Various Plants - Rich Sources for a New Group of Multi-Potent Plant Extracts. Molecules 2009, 14, 2016-2031. [CrossRef]

7. Csuk, R.; Schmuck, K.; Schafer, R. A practical synthesis of betulinic acid. Tetrahedron Lett. 2006, 47, 8769-8770. [CrossRef]

8. Menard, H.; Cirtiu, C.M.; Lalancette, J.; Ruest, L.; Kaljaca, Z. Preparation of Betulinic Acid, Useful as e.g. Antitumor, Antiinflammatory Agent, Comprises Oxidizing Electrochemically Betulin to the Aldehyde; and Further Oxidizing to the Acid. U.S. Patent WO2006063464-A1, 2006.

9. Roshchin, V.I.; Shabanova, N.Y.; Vedernikov, D.N. Synthesis of Betulinic Acid, Comprises Oxidation of Betuline with a Pyridine Dichromate Complex and Acetic Anhydride, Reduction of Betulonic Acid and Recrystallization. U.S. Patent RU2190622-C1, 2003.

10. Liu, J.; Fu, M.L.; Chen, Q.H. Biotransformation optimization of betulin into betulinic acid production catalysed by cultured Armillaria luteo-virens Sacc ZJUQH100-6 cells. J. Appl. Microbiol. 2011, 110, 90-97. [CrossRef]

11. Augustin, J.M.; Kuzina, V.; Andersen, S.B.; Bak, S. Molecular activities, biosynthesis and evolution of triterpenoid saponins. Phytochemistry 2011, 72, 435-457. [CrossRef]

12. Ajikumar, P.K.; Xiao, W.H.; Tyo, K.E.J.; Wang, Y.; Simeon, F.; Leonard, E.; Mucha, O.; Phon, T.H.; Pfeifer, B.; Stephanopoulos, G. Isoprenoid Pathway Optimization for Taxol Precursor Overproduction in Escherichia coli. Science 2010, 330, 70-74. [CrossRef]

13. Paddon, C.J.; Westfall, P.J.; Pitera, D.J.; Benjamin, K.; Fisher, K.; McPhee, D.; Leavell, M.D.; Tai, A.; Main, A.; Eng, D.; et al. High-level semi-synthetic production of the potent antimalarial artemisinin. Nature 2013, 496, 528. [CrossRef]

14. Ro, D.K.; Paradise, E.M.; Ouellet, M.; Fisher, K.J.; Newman, K.L.; Ndungu, J.M.; Ho, K.A.; Eachus, R.A.; Ham, T.S.; Kirby, J.; et al. Production of the antimalarial drug precursor artemisinic acid in engineered yeast. Nature 2006, 440, 940-943. [CrossRef]

15. Wu, J.; Niu, Y.; Bakur, A.; Li, H.; Chen, Q. Cell-Free Production of Pentacyclic Triterpenoid Compound Betulinic Acid from Betulin by the Engineered Saccharomyces cerevisiae. Molecules 2017, 22, 1075. [CrossRef] [PubMed]

16. Kumar, D.; Dubey, K.K. An efficient process for the transformation of betulin to betulinic acid by a strain of Bacillus megaterium. 3 Biotech 2017, 7, 157. [CrossRef] [PubMed]

17. Mukherjee, D.; Kumar, N.S.; Khatua, T.; Mukherjee, P.K. Rapid Validated HPTLC Method for Estimation of Betulinic acid in Nelumbo nucifera (Nymphaeaceae) Rhizome Extract. Phytochem. Anal. 2010, 21, 556-560. [CrossRef]

18. Kim, H.I.; Quan, F.S.; Kim, J.E.; Lee, N.R.; Kim, H.J.; Jo, S.J.; Lee, C.M.; Jang, D.S.; Inn, K.S. Inhibition of estrogen signaling through depletion of estrogen receptor alpha by ursolic acid and betulinic acid from Prunella vulgaris var. lilacina. Biochem. Biophys. Res. Commun. 2014, 451, 282-287. [CrossRef]

19. Elusiyan, C.A.; Msagati, T.A.M.; Shode, F.O.; Mamba, B.B. Measurements of distribution coefficients and lipophilicity values for oleanolic acid and betulinic acid extracted from indigenous plants by hollow fibre supported liquid membrane. Bull. Chem. Soc. Ethiop. 2011, 25, 321-332. [CrossRef]

20. Liu, J.; Chen, P.; Yao, W.J.; Wang, J.; Wang, L.Y.; Deng, L.H.; He, J.; Zhang, G.F.; Lei, J.D. Subcritical water extraction of betulinic acid from birch bark. Ind. Crop. Prod. 2015, 74, 557-565. [CrossRef]

21. Bruckner, V.; Kovacs, J.; Koczka, I. Occurrence of betulinic acid in the bark of the plane tree. J. Chem. Soc. 1948, 948-951. [CrossRef]

22. Galgon, T.; Hoke, D.; Drager, B. Identification and quantification of betulinic acid. Phytochem. Anal. 1999, 10, 187-190. [CrossRef]

23. Pinilla, J.M.; Lopez-Padilla, A.; Vicente, G.; Fornari, T.; Quintela, J.C.; Reglero, G. Recovery of betulinic acid from plane tree (Platanus acerifolia L.). J. Supercrit. Fluids 2014, 95, 541-545. [CrossRef]

24. Aisha, A.F.A.; Abu-Salah, K.M.; Alrokayan, S.A.; Siddiqui, M.J.; Ismail, Z.; Majid, A. Syzygium aromaticum extracts as good source of betulinic acid and potential anti-breast cancer. Rev. Bras. Farmacogn. Braz. J. Pharmacogn. 2012, 22, 335-343. [CrossRef]

25. Domingues, R.M.A.; de Melo, M.M.R.; Oliveira, E.L.G.; Neto, C.P.; Silvestre, A.J.D.; Silva, C.M. Optimization of the supercritical fluid extraction of triterpenic acids from Eucalyptus globulus bark using experimental design. J. Supercrit. Fluids 2013, 74, 105-114. [CrossRef]

26. Domingues, R.M.A.; Sousa, G.D.A.; Freire, C.S.R.; Silvestre, A.J.D.; Neto, C.P. Eucalyptus globulus biomass residues from pulping industry as a source of high value triterpenic compounds. Ind. Crop. Prod. 2010, 31, 65-70. [CrossRef] 
27. Freire, C.S.R.; Silvestre, A.J.D.; Neto, C.P.; Cavaleiro, J.A.S. Lipophilic extractives of the inner and outer barks of Eucalyptus globulus. Holzforschung 2002, 56, 372-379. [CrossRef]

28. Domingues, R.M.A.; Sousa, G.D.A.; Silva, C.M.; Freire, C.S.R.; Silvestre, A.J.D.; Neto, C.P. High value triterpenic compounds from the outer barks of several Eucalyptus species cultivated in Brazil and in Portugal. Ind. Crop. Prod. 2011, 33, 158-164. [CrossRef]

29. Tezuka, Y.; Stampoulis, P.; Banskota, A.H.; Awale, S.; Tran, K.Q.; Saiki, I.; Kadota, S. Constituents of the Vietnamese medicinal plant Orthosiphon stamineus. Chem. Pharm. Bull. 2000, 48, 1711-1719. [CrossRef]

30. Machado, D.G.; Cunha, M.P.; Neis, V.B.; Balen, G.O.; Colla, A.; Bettio, L.E.B.; Oliveira, A.; Pazini, F.L.; Dalmarco, J.B.; Simionatto, E.L.; et al. Antidepressant-like effects of fractions, essential oil, carnosol and betulinic acid isolated from Rosmarinus officinalis L. Food Chem. 2013, 136, 999-1005. [CrossRef]

31. Nyasse, B.; Nono, J.J.; Nganso, Y.; Ngantchou, I.; Schneider, B. Uapaca genus (Euphorbiaceae), a good source of betulinic acid. Fitoterapia 2009, 80, 32-34. [CrossRef]

32. Sun, Y.F.; Song, C.K.; Viemstein, H.; Unger, F.; Liang, Z.S. Apoptosis of human breast cancer cells induced by microencapsulated betulinic acid from sour jujube fruits through the mitochondria transduction pathway. Food Chem. 2013, 138, 1998-2007. [CrossRef]

33. Zhang, M.C.; Zhang, Y.Q.; Xie, J.B. Simultaneous determination of jujuboside A, B and betulinic acid in semen Ziziphi spinosae by high performance liquid chromatography-evaporative light scattering detection. J. Pharm. Biomed. Anal. 2008, 48, 1467-1470. [CrossRef]

34. Adesanwo, J.K.; Makinde, O.O.; Obafemi, C.A.J.J.o.P.R. Phytochemical analysis and antioxidant activity of methanol extract and betulinic acid isolated from the roots of Tetracera potatoria. J. Pharm. Res. 2013, 6, 903-907. [CrossRef]

35. Puniani, E.; Cayer, C.; Kent, P.; Mullally, M.; Sanchez-Vindas, P.; Alvarez, L.P.; Cal, V.; Merali, Z.; Arnason, J.T.; Durst, T. Ethnopharmacology of Souroubea sympetala and Souroubea gilgii (Marcgraviaceae) and identification of betulinic acid as an anxiolytic principle. Phytochemistry 2015, 113, 73-78. [CrossRef]

36. Jeong, W.; Hong, S.S.; Kim, N.; Yang, Y.T.; Shin, Y.S.; Lee, C.; Hwang, B.Y.; Lee, D. Bioactive triterpenoids from Callistemon lanceolatus. Arch. Pharmacal Res. 2009, 32, 845-849. [CrossRef] [PubMed]

37. Lin, C.K.; Tseng, C.K.; Chen, K.H.; Wu, S.H.; Liaw, C.C.; Lee, J.C. Betulinic acid exerts anti-hepatitis C virus activity via the suppression of NF-kappa B- and MAPK-ERK1/2-mediated COX-2 expression. Br. J. Pharmacol. 2015, 172, 4481-4492. [CrossRef] [PubMed]

38. Kim, D.; Chen, Z.D.; Nguyen, V.T.; Pezzuto, J.M.; Qiu, S.X.; Lu, Z.Z. A concise semi-synthetic approach to betulinic acid from betulin. Synth. Commun. 1997, 27, 1607-1612. [CrossRef]

39. Kim, D.S.H.L.; Pezzuto, J.M. Manufacturing Beta Isomer of Betulinic Acid - Oxidising Betulin, Reducing the Product to Convert Keto Functionality to Secondary Alcohol and Separating and Purifying the Beta Isomer. U.S. Patent US5804575-A, 1998.

40. Gaudet, D.; Pichette, A. Process for Preparing Natural Product Derivatives from Plants in a Single Step, Particularly for Preparing Derivatives of Betulin or Lupeol from Birch Bark. U.S. Patent WO200026174-A2, 2000.

41. Krasutsky, P.A.; Carlson, R.M.; Nesterenko, V.V. Preparation of Betulin-3-Acetate Useful for Preparation of Betulinic acid Involves Acylating Betulin Followed by Alcoholyzing Obtained Betulin-3,28-Diacetate. U.S. Patent US2001007908-A1, 2001.

42. Krasutsky, P.A.; Kolomitsyna, O.; Krasutsky, P. Preparation of 3-Esters of Betulinic Aldehyde Useful for Treating e.g. HIV, Herpes, Hepatitis, Cancer, Viral, Fungal and/or Bacterial Infection Involves Contacting Betulin Aldehyde with Keto Compound or Substituted Furan-2,5-Dione Compound. U.S. Patent WO2006105356-A2, 2007.

43. Chen, Q.H.; Liu, J.; Zhang, H.F.; He, G.Q.; Fu, M.L. The betulinic acid production from betulin through biotransformation by fungi. Enzym. Microb. Technol. 2009, 45, 175-180. [CrossRef]

44. Fu, M.L.; Liu, J.; Dong, Y.C.; Feng, Y.; Fang, R.S.; Chen, Q.H.; Liu, X.J. Effect of ionic liquid-containing system on betulinic acid production from betulin biotransformation by cultured Armillaria luteo-virens Sacc cells. Eur. Food Res. Technol. 2011, 233, 507-515. [CrossRef]

45. Feng, Y.; Li, M.; Liu, J.; Xu, T.Y.; Fang, R.S.; Chen, Q.H.; He, G.Q. A novel one-step microbial transformation of betulin to betulinic acid catalysed by Cunninghamella blakesleeana. Food Chem. 2013, 136, 73-79. [CrossRef] [PubMed]

46. Qazi, M.S.; Sultana, N.; Kamal, M. Biotransformation of pentacyclic terpene isolated from Alstonia scholaris (R.BR.). Biocatal. Biotransformation 2013, 31, 148-152. [CrossRef]

47. Zhang, S.; Xie, Y.; Tan, Y.; Chen, H.; Mei, R.; Dong, X.; Wu, B. Triterpenoids of Inonotus obliquus. Chin. Tradit. Herb. Drugs 2015, $46,2355-2360$.

48. Lou, H.; Li, H.; Wei, T.; Chen, Q. Stimulatory Effects of Oleci Acid and Fungal Elicitor on Betulinic Acid Production by Submerged Cultivation of Medicinal Mushroom Inonotus obliquus. J. Fungi 2021, 7, 266. [CrossRef]

49. Tsiri, D.; Aligiannis, N.; Graikou, K.; Spyropoulos, C.; Chinou, I. Triterpenoids from Eucalyptus camaldulensis DEHNH. Tissue Cultures. Helv. Chim. Acta 2008, 91, 2110-2114. [CrossRef]

50. Herrera, J.B.R.; Bartel, B.; Wilson, W.K.; Matsuda, S.P.T. Cloning and characterization of the Arabidopsis thaliana lupeol synthase gene. Phytochemistry 1998, 49, 1905-1911. [CrossRef]

51. Morita, M.; Shibuya, M.; Kushiro, T.; Masuda, K.; Ebizuka, Y.J.F.J. Molecular cloning and functional expression of triterpene synthases from pea (Pisum sativum) new alpha-amyrin-producing enzyme is a multifunctional triterpene synthase. Eur. J. Biochem. 2010, 267, 3453-3460. [CrossRef] [PubMed]

52. Suzuki, H.; Achnine, L.; Xu, R.; Matsuda, S.P.T.; Dixon, R.A. A genomics approach to the early stages of triterpene saponin biosynthesis in Medicago truncatula. Plant J. 2002, 32, 1033-1048. [CrossRef] [PubMed] 
53. Iturbe-Ormaetxe, I.; Haralampidis, K.; Papadopoulou, K.; Osbourn, A.E. Molecular cloning and characterization of triterpene synthases from Medicago truncatula and Lotus japonicus. Plant Mol. Biol. 2003, 51, 731-743. [CrossRef] [PubMed]

54. Kushiro, T.; Shibuya, M.; Ebizuka, Y. beta-Amyrin synthase-Cloning of oxidosqualene cyclase that catalyzes the formation of the most popular triterpene among higher plants. Eur. J. Biochem. 1998, 256, 238-244. [CrossRef]

55. Fukushima, E.O.; Seki, H.; Ohyama, K.; Ono, E.; Umemoto, N.; Mizutani, M.; Saito, K.; Muranaka, T. CYP716A Subfamily Members are Multifunctional Oxidases in Triterpenoid Biosynthesis. Plant Cell Physiol. 2011, 52, 2050-2061. [CrossRef]

56. Huang, L.L.; Li, J.; Ye, H.C.; Li, C.F.; Wang, H.; Liu, B.Y.; Zhang, Y.S. Molecular characterization of the pentacyclic triterpenoid biosynthetic pathway in Catharanthus roseus. Planta 2012, 236, 1571-1581. [CrossRef] [PubMed]

57. Li, J.; Zhang, Y.S. Increase of betulinic acid production in Saccharomyces cerevisiae by balancing fatty acids and betulinic acid forming pathways. Appl. Microbiol. Biotechnol. 2014, 98, 3081-3089. [CrossRef]

58. Li, J.; Zhang, Y.S. Modulating betulinic acid production in Saccharomyces cerevisiae by managing the intracellular supplies of the co-factor NADPH and oxygen. J. Biosci. Bioeng. 2015, 119, 77-81. [CrossRef]

59. Pisha, E.; Chai, H.; Lee, I.-S.; Chagwedera, T.E.; Farnsworth, N.R.; Cordell, G.A.; Beecher, C.W.W.; Fong, H.H.S.; Kinghorn, A.D.; Brown, D.M.; et al. Discovery of betulinic acid as a selective inhibitor of human melanoma that functions by induction of apoptosis. Nat. Med. 1995, 1, 1046-1051. [CrossRef] [PubMed]

60. Wang, G.; Wang, Y.Z.; Yu, Y.; Yin, P.H.; Xu, K.J.J.o.B.N. The Antitumor Activity of Betulinic Acid-Loaded Nanoliposomes Against Colorectal Cancer In Vitro and In Vivo via Glycolytic and Glutaminolytic Pathways. J. Biomed. Nanotechnol. 2020, 16, $235-251$. [CrossRef]

61. Mullauer, F.B.; van Bloois, L.; Daalhuisen, J.B.; Ten Brink, M.S.; Storm, G.; Medema, J.P.; Schiffelers, R.M.; Kessler, J.H. Betulinic acid delivered in liposomes reduces growth of human lung and colon cancers in mice without causing systemic toxicity. Anti-Cancer Drugs 2011, 22, 223-233. [CrossRef] [PubMed]

62. Poon, K.H.; Zhang, J.; Wang, C.; Tse, A.K.; Wan, C.K.; Fong, W.F. Betulinic acid enhances 1alpha,25-dihydroxyvitamin D3-induced differentiation in human HL-60 promyelocytic leukemia cells. Anti-Cancer Drugs 2004, 15, 619-624. [CrossRef]

63. Faujan, N.H.; Alitheen, N.B.; Yeap, S.K.; Ali, A.M.; Muhajir, A.H.; Ahmad, F.B.H. Cytotoxic effect of betulinic acid and betulinic acid acetate isolated from Melaleuca cajuput on human myeloid leukemia (HL-60) cell line. Afr. J. Biotechnol. 2010, 9, 6387-6396.

64. Khan, I.; Guru, S.K.; Rath, S.K.; Chinthakindi, P.K.; Singh, B.; Koul, S.; Bhushan, S.; Sangwan, P.L. A novel triazole derivative of betulinic acid induces extrinsic and intrinsic apoptosis in human leukemia HL-60 cells. Eur. J. Med. Chem. 2016, 108, 104-116. [CrossRef]

65. Ehrhardt, H.; Fulda, S.; Fuhrer, M.; Debatin, K.M.; Jeremias, I. Betulinic acid-induced apoptosis in leukemia cells. Leukemia 2004, 18, 1406-1412. [CrossRef]

66. Wu, Q.L.; He, J.; Fang, J.; Hong, M. Antitumor effect of betulinic acid on human acute leukemia K562 cells in vitro. J. Huazhong Univ. Sci. Technol. Med Sci. 2010, 30, 453-457. [CrossRef]

67. Kessler, J.H.; Mullauer, F.B.; de Roo, G.M.; Medema, J.P. Broad in vitro efficacy of plant-derived betulinic acid against cell lines derived from the most prevalent human cancer types. Cancer Lett. 2007, 251, 132-145. [CrossRef] [PubMed]

68. Chintharlapalli, S.; Papineni, S.; Lei, P.; Pathi, S.; Safe, S. Betulinic acid inhibits colon cancer cell and tumor growth and induces proteasome-dependent and -independent downregulation of specificity proteins (Sp) transcription factors. Bmc Cancer 2011, 11. [CrossRef] [PubMed]

69. Jung, G.R.; Kim, K.J.; Choi, C.H.; Lee, T.B.; Han, S.I.; Han, H.K.; Lim, S.C. Effect of betulinic acid on anticancer drug-resistant colon cancer cells. Basic Clin. Pharmacol. Toxicol. 2007, 101, 277-285. [CrossRef] [PubMed]

70. Aisha, A.F.A.; Abu-Salah, K.M.; Ismail, Z.; Majid, A. alpha-Mangostin Enhances Betulinic Acid Cytotoxicity and Inhibits Cisplatin Cytotoxicity on HCT 116 Colorectal Carcinoma Cells. Molecules 2012, 17, 2939-2954. [CrossRef] [PubMed]

71. Rabi, T.; Shukla, S.; Gupta, S. Betulinic Acid Suppresses Constitutive and TNF alpha-Induced NF-kappa B Activation and Induces Apoptosis in Human Prostate Carcinoma PC-3 Cells. Mol. Carcinog. 2008, 47, 964-973. [CrossRef]

72. Reiner, T.; de Las Pozas, A.; Parrondo, R.; Palenzuela, D.; Cayuso, W.; Rai, P.; Perez-Stable, C. Mcl-1 protects prostate cancer cells from cell death mediated by chemotherapy-induced DNA damage. Oncoscience 2015, 2, 703-715. [CrossRef]

73. Pandey, M.K.; Sung, B.; Aggarwal, B.B. Betulinic acid suppresses STAT3 activation pathway through induction of protein tyrosine phosphatase SHP-1 in human multiple myeloma cells. Int. J. Cancer 2010, 127, 282-292. [CrossRef]

74. Potze, L.; Di Franco, S.; Grandela, C.; Pras-Raves, M.L.; Picavet, D.I.; van Veen, H.A.; van Lenthe, H.; Mullauer, F.B.; van der Wel, N.N.; Luyf, A.; et al. Betulinic acid induces a novel cell death pathway that depends on cardiolipin modification. Oncogene 2016, 35, 427-437. [CrossRef]

75. Gopal, D.V.R.; Narkar, A.A.; Badrinath, Y.; Mishra, K.P.; Joshi, D.S. Betulinic acid induces apoptosis in human chronic myelogenous leukemia (CML) cell line K-562 without altering the levels of Bcr-Abl. Toxicol. Lett. 2005, 155, 343-351. [CrossRef]

76. Costa, J.F.; Barbosa-Filho, J.M.; Maia, G.L.; Guimaraes, E.T.; Meira, C.S.; Ribeiro-dos-Santos, R.; de Carvalho, L.C.; Soares, M.B. Potent anti-inflammatory activity of betulinic acid treatment in a model of lethal endotoxemia. Int. Immunopharmacol. 2014, 23, 469-474. [CrossRef]

77. Lingaraju, M.C.; Pathak, N.N.; Begum, J.; Balaganur, V.; Bhat, R.A.; Ramachandra, H.D.; Ayanur, A.; Ram, M.; Singh, V.; Kumar, D.; et al. Betulinic acid attenuates lung injury by modulation of inflammatory cytokine response in experimentally-induced polymicrobial sepsis in mice. Cytokine 2015, 71, 101-108. [CrossRef] 
78. Nader, M.A.; Baraka, H.N. Effect of betulinic acid on neutrophil recruitment and inflammatory mediator expression in lipopolysaccharide-induced lung inflammation in rats. Eur. J. Pharm. Sci. Off. J. Eur. Fed. Pharm. Sci. 2012, 46, 106-113. [CrossRef]

79. Armah, F.A.; Annan, K.; Mensah, A.Y.; Amponsah, I.K.; Tocher, D.A.; Habtemariam, S. Erythroivorensin: A novel antiinflammatory diterpene from the root-bark of Erythrophleum ivorense (A Chev.). Fitoterapia 2015, 105, 37-42. [CrossRef] [PubMed]

80. Viji, V.; Helen, A.; Luxmi, V.R. Betulinic acid inhibits endotoxin-stimulated phosphorylation cascade and pro-inflammatory prostaglandin E2 production in human peripheral blood mononuclear cells. Br. J. Pharmacol. 2011, 162, 1291-1303. [CrossRef] [PubMed]

81. Dunstan, C.A.; Liu, B.L.; Welch, C.J.; Perera, P.; Bohlin, L. Alphitol, a phenolic substance from Alphitonia zizyphoides which inhibits prostaglandin biosynthesis in vitro. Phytochemistry 1998, 48, 495-497. [CrossRef]

82. Recio, M.D.; Giner, R.M.; Manez, S.; Gueho, J.; Julien, H.R.; Hostettmann, K.; Rios, J.L. Investigations on the steroidal antiinflammatory activity of triterpenoids from Diospyros leucomelas. Planta Med. 1995, 61, 9-12. [CrossRef] [PubMed]

83. Manez, S.; Recio, M.C.; Giner, R.M.; Rios, J.L. Effect of selected triterpenoids on chronic dermal inflammation. Eur. J. Pharmacol. 1997, 334, 103-105. [CrossRef]

84. Mukherjee, P.K.; Saha, K.; Das, J.; Pal, M.; Saha, B.P. Studies on the anti-inflammatory activity of rhizomes of Nelumbo nucifera. Planta Med. 1997, 63, 367-369. [CrossRef]

85. Krogh, R.; Kroth, R.; Berti, C.; Madeira, A.O.; Souza, M.M.; Cechinel, V.; Delle-Monache, F.; Yunes, R.A. Isolation and identification of compounds with antinociceptive action from Ipomoea pes-caprae (L.) R-Br. Pharmazie 1999, 54, 464-466.

86. Ryu, S.Y.; Oak, M.H.; Yoon, S.K.; Cho, D.I.; Yoo, G.S.; Kim, T.S.; Kim, K.M. Anti-allergic and anti-inflammatory triterpenes from the herb of Prunella vulgaris. Planta Med. 2000, 66, 358-360. [CrossRef]

87. Huguet, A.I.; Recio, M.D.; Manez, S.; Giner, R.M.; Rios, J.L. Effect of triterpenoids on the inflammation induced by protein kinase C activators, neuronally acting irritants and other agents. Eur. J. Pharmacol. 2000, 410, 69-81. [CrossRef]

88. Fujioka, T.; Kashiwada, Y.; Kilkuskie, R.E.; Cosentino, L.M.; Ballas, L.M.; Jiang, J.B.; Janzen, W.P.; Chen, I.S.; Lee, K.H. Anti-AIDS agents, 11. Betulinic acid and platanic acid as anti-HIV principles from Syzigium claviflorum, and the anti-HIV activity of structurally related triterpenoids. J. Nat. Prod. 1994, 57, 243-247. [CrossRef]

89. Akihisa, T.; Ogihara, J.; Kato, J.; Yasukawa, K.; Ukiya, M.; Yamanouchi, S.; Oishi, K. Inhibitory effects of triterpenoids and sterols on human immunodeficiency virus-1 reverse transcriptase. Lipids 2001, 36, 507-512. [CrossRef] [PubMed]

90. Mayaux, J.F.; Bousseau, A.; Pauwels, R.; Huet, T.; Henin, Y.; Dereu, N.; Evers, M.; Soler, F.; Poujade, C.; Declercq, E.; et al. Triterpene derivatives that block entry of human immunodeficiency virus type 1 into cells. Proc. Natl. Acad. Sci. USA 1994, 91, 3564-3568. [CrossRef] [PubMed]

91. Xu, H.X.; Zeng, F.Q.; Wan, M.; Sim, K.Y. Anti-HIV triterpene acids from Geum japonicum. J. Nat. Prod. 1996, 59, 643-645. [CrossRef] [PubMed]

92. Kim, S.J.; Quan, H.Y.; Jeong, K.J.; Kim, D.Y.; Kim, G.; Jo, H.K.; Chung, S.H. Beneficial effect of betulinic acid on hyperglycemia via suppression of hepatic glucose production. J. Agric. Food Chem. 2014, 62, 434-442. [CrossRef]

93. Yoon, J.J.; Lee, Y.J.; Han, B.H.; Choi, E.S.; Kho, M.C.; Park, J.H.; Ahn, Y.M.; Kim, H.Y.; Kang, D.G.; Lee, H.S. Protective effect of betulinic acid on early atherosclerosis in diabetic apolipoprotein-E gene knockout mice. Eur. J. Pharm. 2017, 796, 224-232 [CrossRef]

94. Xie, R.; Zhang, H.; Wang, X.Z.; Yang, X.Z.; Wu, S.N.; Wang, H.G.; Shen, P.; Ma, T.H. The protective effect of betulinic acid (BA) diabetic nephropathy on streptozotocin (STZ)-induced diabetic rats. Food Funct. 2017, 8, 299-306. [CrossRef]

95. Ahangarpour, A.; Oroojan, A.A.; Khorsandi, L.; Shabani, R.; Mojaddami, S. Preventive effects of betulinic acid on streptozotocinnicotinamide induced diabetic nephropathy in male mouse. J. Nephropathol. 2016, 5, 128-133. [CrossRef]

96. Ahangarpour, A.; Oroojan, A.A.; Khorsandi, L.; Arzani, G.; Afshari, G. Effects of Betulinic Acid on the Male Reproductive System of a Streptozotocin-Nicotinamide-Induced Diabetic Mouse Model. World J. Men's Health 2016, 34, 209-216. [CrossRef]

97. Wang, S.; Yang, Z.; Xiong, F.; Chen, C.; Chao, X.; Huang, J.; Huang, H. Betulinic acid ameliorates experimental diabetic-induced renal inflammation and fibrosis via inhibiting the activation of NF-kappaB signaling pathway. Mol. Cell. Endocrinol. 2016, 434, 135-143. [CrossRef] [PubMed]

98. Steele, J.C.P.; Warhurst, D.C.; Kirby, G.C.; Simmonds, M.S.J. In vitro andIn vivo evaluation of betulinic acid as an antimalarial. Phytother. Res. 1999, 13, 115-119. [CrossRef]

99. de Sa, M.S.; Costa, J.F.O.; Krettli, A.U.; Zalis, M.G.; Maia, G.L.D.; Sette, I.M.F.; Camara, C.D.; Barbosa, J.M.; Giulietti-Harley, A.M.; dos Santos, R.R.; et al. Antimalarial activity of betulinic acid and derivatives in vitro against Plasmodium falciparum and in vivo in P-berghei-infected mice. Parasitol. Res. 2009, 105, 275-279. [CrossRef]

100. Olanlokun, J.O.; Okoro, P.O.; Lawal, O.S.; Bodede, O.; Olotu, F.; Idowu, T.O.; Prinsloo, G.; Soliman, M.E.; Olorunsogo, O.O Betulinic acid purified from Alstonia boonei inhibits folate biosynthesis in malarial Plasmodium, enhances mitochondrial pore opening and F1F0 ATPase in mice. J. Mol. Struct. 2021, 1239. [CrossRef]

101. Apoptosis in liver during malaria: Role of oxidative stress and implication of mitochondrial pathway. FASEB J. 2006, 20, 1224-1226. [CrossRef] 
102. Karagoz, A.C.; Leidenberger, M.; Hahn, F.; Hampel, F.; Friedrich, O.; Marschall, M.; Kappes, B.; Tsogoeva, S.B. Synthesis of new betulinic acid/betulin-derived dimers and hybrids with potent antimalarial and antiviral activities. Bioorg. Med. Chem. 2019, 27, 110-115. [CrossRef] [PubMed]

103. Cargnin, S.T.; Staudt, A.F.; Medeiros, P.; de Medeiros Sol Sol, D.; de Azevedo Dos Santos, A.P.; Zanchi, F.B.; Gosmann, G.; Puyet, A.; Garcia Teles, C.B.; Gnoatto, S.B. Semisynthesis, cytotoxicity, antimalarial evaluation and structure-activity relationship of two series of triterpene derivatives. Bioorg. Med. Chem. Lett. 2018, 28, 265-272. [CrossRef]

104. Szuster-Ciesielska, A.; Plewka, K.; Daniluk, J.; Kandefer-Szerszen, M. Betulin and betulinic acid attenuate ethanol-induced liver stellate cell activation by inhibiting reactive oxygen species (ROS), cytokine (TNF-alpha, TGF-beta) production and by influencing intracellular signaling. Toxicology 2011, 280, 152-163. [CrossRef]

105. Jain, M.; Kapadia, R.; Jadeja, R.N.; Thounaojam, M.C.; Devkar, R.V.; Mishra, S.H. Hepatoprotective potential of Tecomella undulata stem bark is partially due to the presence of betulinic acid. J. Ethnopharmacol. 2012, 143, 194-200. [CrossRef]

106. Yi, J.; Xia, W.; Wu, J.; Yuan, L.; Wu, J.; Tu, D.; Fang, J.; Tan, Z. Betulinic acid prevents alcohol-induced liver damage by improving the antioxidant system in mice. J. Vet. Sci. 2014, 15, 141. [CrossRef]

107. Wan, Y.; Wu, Y.L.; Lian, L.H.; Xie, W.X.; Li, X.; Ouyang, B.Q.; Bai, T.; Li, Q.; Yang, N.; Nan, J.X. The anti-fibrotic effect of betulinic acid is mediated through the inhibition of NF-kappaB nuclear protein translocation. Chem. -Biol. Interact. 2012, 195, 215-223. [CrossRef] [PubMed]

108. Wynn, T.A. Common and unique mechanisms regulate fibrosis in various fibroproliferative diseases. J. Clin. Investig. 2007, 117, 524-529. [CrossRef] [PubMed]

109. Sharma, A.; Thakur, R.; Lingaraju, M.C.; Kumar, D.; Mathesh, K.; Telang, A.G.; Singh, T.U.; Kumar, D. Betulinic acid attenuates renal fibrosis in rat chronic kidney disease model. Biomed. Pharmacother. Biomed. Pharmacother. 2017, 89, 796-804. [CrossRef]

110. Xia, A.; Xue, Z.; Li, Y.; Wang, W.; Xia, J.; Wei, T.; Cao, J.; Zhou, W. Cardioprotective effect of betulinic Acid on myocardial ischemia reperfusion injury in rats. Evid. -Based Complementary Altern. Med. Ecam. 2014, 2014, 573745. [CrossRef]

111. Lu, Q.; Xia, N.; Xu, H.; Guo, L.; Wenzel, P.; Daiber, A.; Munzel, T.; Forstermann, U.; Li, H. Betulinic acid protects against cerebral ischemia-reperfusion injury in mice by reducing oxidative and nitrosative stress. Nitric Oxide Biol. Chem. Off. J. Nitric Oxide Soc. 2011, 24, 132-138. [CrossRef]

112. Afzal, M.; Kazmi, I.; Semwal, S.; Al-Abbasi, F.A.; Anwar, F. Therapeutic exploration of betulinic acid in chemically induced hypothyroidism. Mol. Cell. Biochem. 2014, 386, 27-34. [CrossRef]

113. Jine, Y.; Lis, M.; Szczypka, M.; Obmińska-Mrukowicz, B. Influence of betulinic acid on lymphocyte subsets and humoral immune response in mice. Pol. J. Vet. Sci. 2012, 15. [CrossRef]

114. Kim, J.; Lee, Y.S.; Kim, C.S.; Kim, J.S. Betulinic acid has an inhibitory effect on pancreatic lipase and induces adipocyte lipolysis. Phytother. Res. PTR 2012, 26, 1103-1106. [CrossRef]

115. Mullally, M.; Mimeault, C.; Otárola Rojas, M.; Sanchez Vindas, P.; Garcia, M.; Poveda Alvarez, L.; Moon, T.W.; Gilmour, K.M.; Trudeau, V.L.; Arnason, J.T. A botanical extract of Souroubea sympetala and its active principle, betulinic acid, attenuate the cortisol response to a stressor in rainbow trout, Oncorhynchus mykiss. Aquaculture 2017, 468, 26-31. [CrossRef] 